\title{
Physical separation, mechanical enrichment and recycling-oriented characterization of spent NiMH batteries
}

\author{
Burçak Ebin $^{1}$ (1) $\cdot$ Martina Petranikova ${ }^{1} \cdot$ Christian Ekberg $^{1}$
}

Received: 29 December 2017 / Accepted: 29 May 2018 / Published online: 7 June 2018

(c) The Author(s) 2018

\begin{abstract}
Nickel-metal hydride (NiMH) batteries contain high amount of industrial metals, especially iron, nickel, cobalt and rare earth elements. Although the battery waste is a considerable secondary source for metal and chemical industries, a recycling process requires a suitable pretreatment method before proceeding with recovery step to reclaim all valuable elements. In this study, AA- and AAA-type spent NiMH batteries were ground and then sieved for size measurement and classification. Chemical composition of the ground battery black mass and sorted six different size fractions were determined by an analytical technique. Crystal structures of the samples were analyzed by X-ray diffraction. Results show that after mechanical treatment, almost $87 \mathrm{wt} \%$ of the spent NiMH batteries are suitable for further recycling steps. Size classification by sieving enriched the iron content of the samples in the coarse fraction which is bigger than $0.25 \mathrm{~mm}$. On the other hand, the amounts of nickel and rare earth elements increased by decreasing sample size, and concentrated in the finer fractions. Anode and cathode active materials that are hydrogen storage alloy and nickel hydroxide were mainly collected in finer size fraction of the battery black mass.
\end{abstract}

Keywords NiMH battery $\cdot$ Spent batteries $\cdot$ Physical separation $\cdot$ Mechanical enrichment $\cdot$ Waste characterization

\section{Introduction}

The importance of electrical energy storage systems have been increasing last two decades due to not only increasing amount of electrical and electronic equipment, hybrid electrical vehicles (HEV) and electrical vehicles (EV), but also growing demand for renewable energy sources [1-3]. Nickel-metal hydride (NiMH) battery is an established energy storage technology which has high volume commercial production for small portable battery applications as well as vehicle packaging for automotive and marine industries [3-6]. These batteries provide most of the critical properties for the general and specific applications, such

Electronic supplementary material The online version of this article (https://doi.org/10.1007/s10163-018-0751-4) contains supplementary material, which is available to authorized users.

Burçak Ebin

burcak@chalmers.se; burcakebin@gmail.com

1 Nuclear Chemistry and Industrial Material Recycling, Department of Chemistry and Chemical Engineering, Chalmers University of Technology, Kemivägen 4, 41296 Göteborg, Sweden as high safety, power, wide range of operating temperature and flexible battery packaging with the choice of cylindrical or prismatic type cells $[4,5]$. For example, cylindrical D-type or prismatic NiMH batteries were used for HEV and/ or EV battery packs [7, 8]. Although Li-ion battery technology began to dominate the vehicle market, the forecast indicates that $\mathrm{NiMH}$ battery demand will slightly increase in the coming years [9].

NiMH battery cell composes of potassium hydroxide $(\mathrm{KOH})$ electrolyte, nickel hydroxide $(\mathrm{NiOH})$ in cathode, hydrogen storage nickel-based alloy in anode, steel cover, current correctors, organic separator and sealing. The common alloys in the electrode designs are $\mathrm{AB}_{5}$ (LaCePrNd$\mathrm{NiCoMnAl}$ ), $\mathrm{A}_{2} \mathrm{~B}_{7}$ (LaCePrNdNiCoMnAl plus $\mathrm{Mg}$ ), and $\mathrm{AB}_{2}$ (VTiZrNiCrCoMnAlSn), where the " $\mathrm{A}_{\mathrm{x}} \mathrm{B}_{\mathrm{y}}$ " refers to the ratio of the A-type elements ( $\mathrm{LaCePrNd}$ or TiZr) to that of the B-type elements (VNiCrCoMnAlSn) [4, 10]. A spent nickel-metal hydride cylindrical type battery composes of about 36-42 wt\% nickel (Ni), 22-25 wt\% iron (Fe) $3-4 \mathrm{wt} \%$ cobalt (Co) and 8-10 wt\% mischmetal consisting of rare earth elements [lanthanum (La), cerium $(\mathrm{Ce})$, praseodymium (Pr) and neodymium (Nd)], 1-2 wt\% potassium (K), 3-4 wt\% plastics and $<1 \mathrm{wt} \%$ graphite $[10,11]$. 
The recycling of spent NiMH batteries is attractive because of not only the high amount of valuable metallic content, but also considerable amount of Co and REE, which are accepted as critical raw material for European Union [12]. For example, a NiMH-type HEV battery pack contains $3.5 \mathrm{~kg}$ REE [13].

The current industrial approach to recycle the NiMH batteries is adding them to the stainless steel production to reclaim the $\mathrm{Ni}, \mathrm{Fe}$ and $\mathrm{Co}$. However, the rest of the elements, especially REEs, stay in the slag, and then difficult to recover them. Recently Umicore (Belgium) and Rhodia (France) developed a combined pyro- and hydro-metallurgical process to recover the REEs $[10,11]$. Several studies have also been conducted on recycling of spent NiMH batteries by hydrometallurgical route. Different leaching reagents (sulfuric acid, nitric acid, hydrochloric acid, hydrogen peroxide, etc.) and various solid-liquid ratios were tested to develop an efficient method to recover the valuable metals [14-19]. After leaching, REEs and other metals can be separated by solvent extraction or precipitation methods [16-19]. Petranikova et al. [20] reported optimization of the pilot-scale process using mixer settlers equipment to separate the valuable metals from the leaching solution. Their results showed that hydrometallurgical method needs several stages to separate the metals.

On the other hand, mechanical pretreatment reduces the material complexity of the spent batteries by the separation of plastics and papers, as well as enriching metal content in the fine fractions for further recycling step. It is generally accepted that mechanical pretreatment of batteries is a necessity before the hydrometallurgical treatment [21-23]. Granata et al. [24] tested 3-step mechanical treatment process including two-rotor crushing, hammer crushing and then thermal treatment. The mechanical route allowed to recover around $40 \%$ of the valuable fractions of NiMH batteries, and the rest, $49 \%$, is smaller than $1 \mathrm{~mm}$ that processed by hydrometallurgical methods to recover the valuable content. Bertuol et al. [25] studied sequential hammer mill and knife mill to grind the spent batteries and applied magnetic separation after the milling steps. The samples classified as non-magnetic, weak and strong magnetic materials. The strong magnetic fraction was a $\mathrm{Fe}-\mathrm{Ni}$ alloy that suitable for secondary steel production as a raw material. The weak magnetic fraction was powder and needs additional recovery processing. Huang et al. [26] investigated mechanical treatment and size classification of the spent NiMH batteries. They showed that sample $>2 \mathrm{~mm}$ size is mainly $\mathrm{Fe}$ and $\mathrm{Ni}$, and smaller fractions than $<2 \mathrm{~mm}$ contain lesser Fe but nearly 5 times higher amount $\mathrm{Ni}$. The distribution of the $\mathrm{Ni}$, $\mathrm{Co}, \mathrm{Zn}$ and REEs were nearly same in the smaller fractions than $<2 \mathrm{~mm}$ size. Tenório et al. [27] presented that about $33 \mathrm{wt} \%$ of the spent battery was recovered as a valuable $\mathrm{Ni}$ and/or alloys by a several step process including milling, magnetic and size separation. According to Tanabe et al. [28], a mechanical pretreatment can efficiently separate metals, polymers and powder fractions of spent NiMH batteries. In addition to these, Czerny and Reichel [29] patented a combined mechanical and heat treatment method for metal recovery from NiMH batteries. After the pretreatment process and size separation, the coarse fraction was recycled by pyrometallurgical approach as ferronickel, and fine fraction was further processed alumina thermal method to reclaim the valuable materials in metallic form. Ruffino et al. [30] studied the mechanical treatment of different types of spent alkaline, $\mathrm{Zn}-\mathrm{C}$ and $\mathrm{Ni}-\mathrm{Cd}$ batteries, and showed that particle size classification and chemical distribution change by battery type.

Although there are some studies on mechanical treatment of the spent NiMH batteries, there are not enough data on elemental distribution in the milled samples according the size classification. This study investigated the mechanical

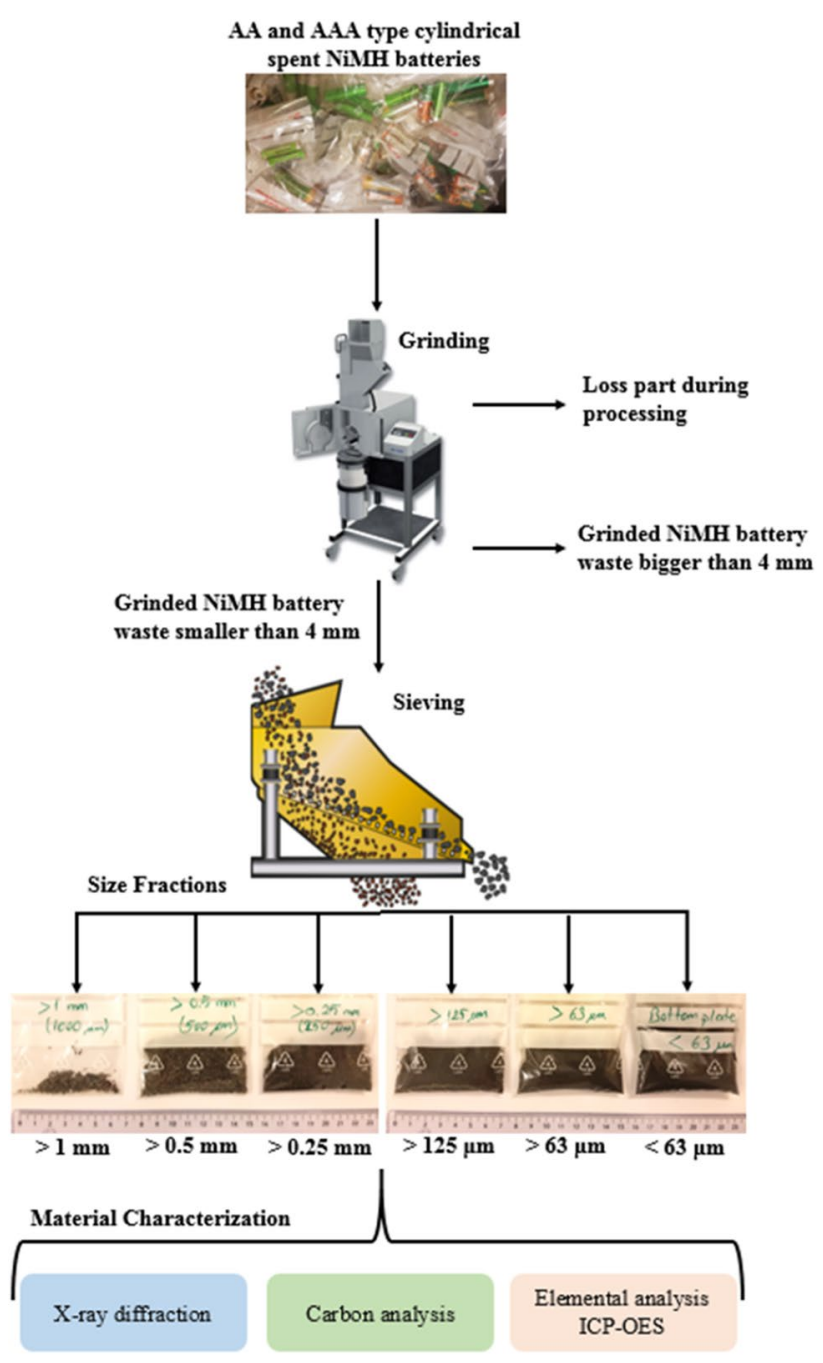

Fig. 1 Process flow and steps of experimental procedure 
pretreatment of AA- and AAA-type cylindrical spent NiMH batteries, and enrichment possibility of the specific metallic contents according to size fractions, which is smaller than $4 \mathrm{~mm}$. The enrichment of the metallic content in different size fractions decreases the complexity of the waste and increases the recycling method options.

\section{Experimental}

The spent NiMH batteries were industrially collected and separated from other types of batteries (alkaline and Li-ion) by Renova AB, Sweden. AA- and AAA-type cylindrical spent NiMH batteries, which belong to various brands and having different capacities, were used. The laboratory process flow with experimental steps is given in Fig. 1. The spent batteries were ground by Retsch SM 300 cutting mill at $2900 \mathrm{~min}^{-1}$ rotation speed with a continuous feeding inlet. A 4-mm sieve was located under the milling chamber and fine battery black mass filled the collection chamber during the mechanical treatment. Figure 2 shows the equipment, illustration of milling step and spent battery samples. Experiments were performed in two sets using 988 and $1007 \mathrm{~g}$ of spent batteries for 5 and 10 min treatment time, respectively. After milling, battery black mass was sorted as undersize sample that are fine powders smaller than $4 \mathrm{~mm}$, oversize sample that are coarser than $4 \mathrm{~mm}$, and loss that are stuck on the equipment as given in Fig. 3.

The quartering method was used to take samples from the fine battery black mass samples for the size classification experiments. Particle size analyses were performed using $1,0.5,0.25,0.125$ and $0.063 \mathrm{~mm}$ size sieves. The images of the samples after sieving test are given in supplementary document. Then all samples were analyzed by material characterization techniques.

X-ray diffraction (XRD, Bruker D8 Advance) using $\mathrm{Cu}$ $\mathrm{K} \alpha$ radiation was used to examine the phase content, crystalline structure and size of the battery waste. The conditions for data collection were continuous scanning of a detector covering a $2 \theta$ angular range from $10^{\circ}$ to $90^{\circ}$ with

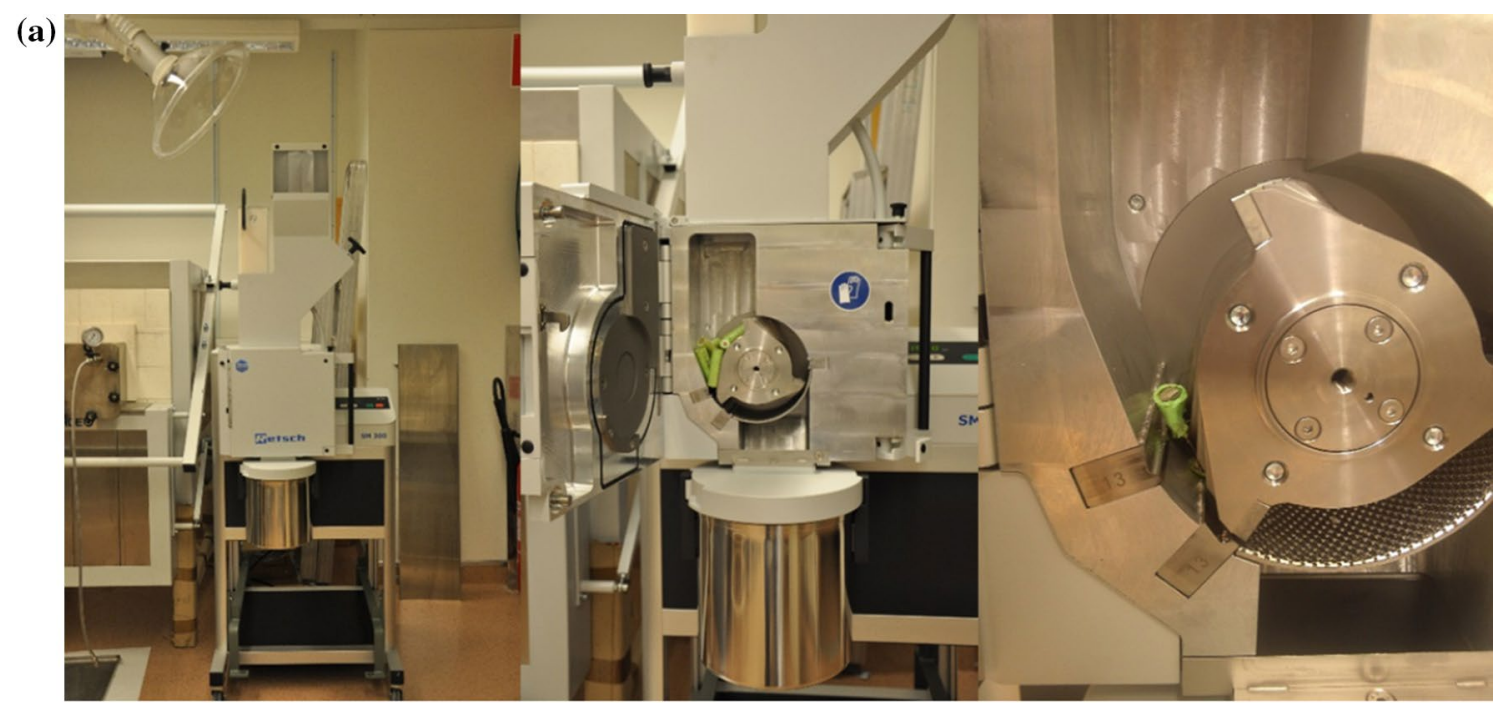

(b)

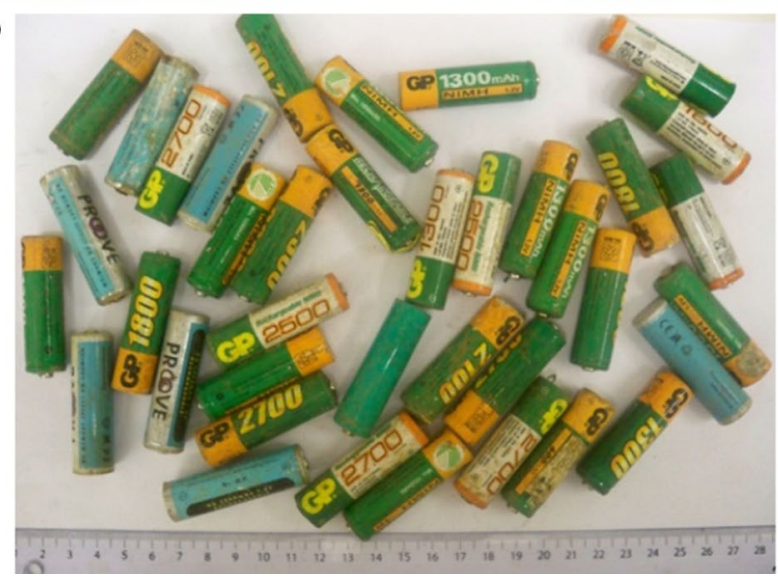

Fig. 2 Images of a grinding equipment, and $\mathbf{b}$ spent NiMH batteries 
Fig. 3 Images of ground samples $\mathbf{a}>4 \mathrm{~mm}$ for $5 \mathrm{~min}$, b $<4 \mathrm{~mm}$ for $5 \mathrm{~min}, \mathbf{c}>4 \mathrm{~mm}$ for $10 \mathrm{~min}, \mathbf{d}<4 \mathrm{~mm}$ for $10 \mathrm{~min}$, and $\mathbf{e}$ the stuck samples on the equipment accepted as loss
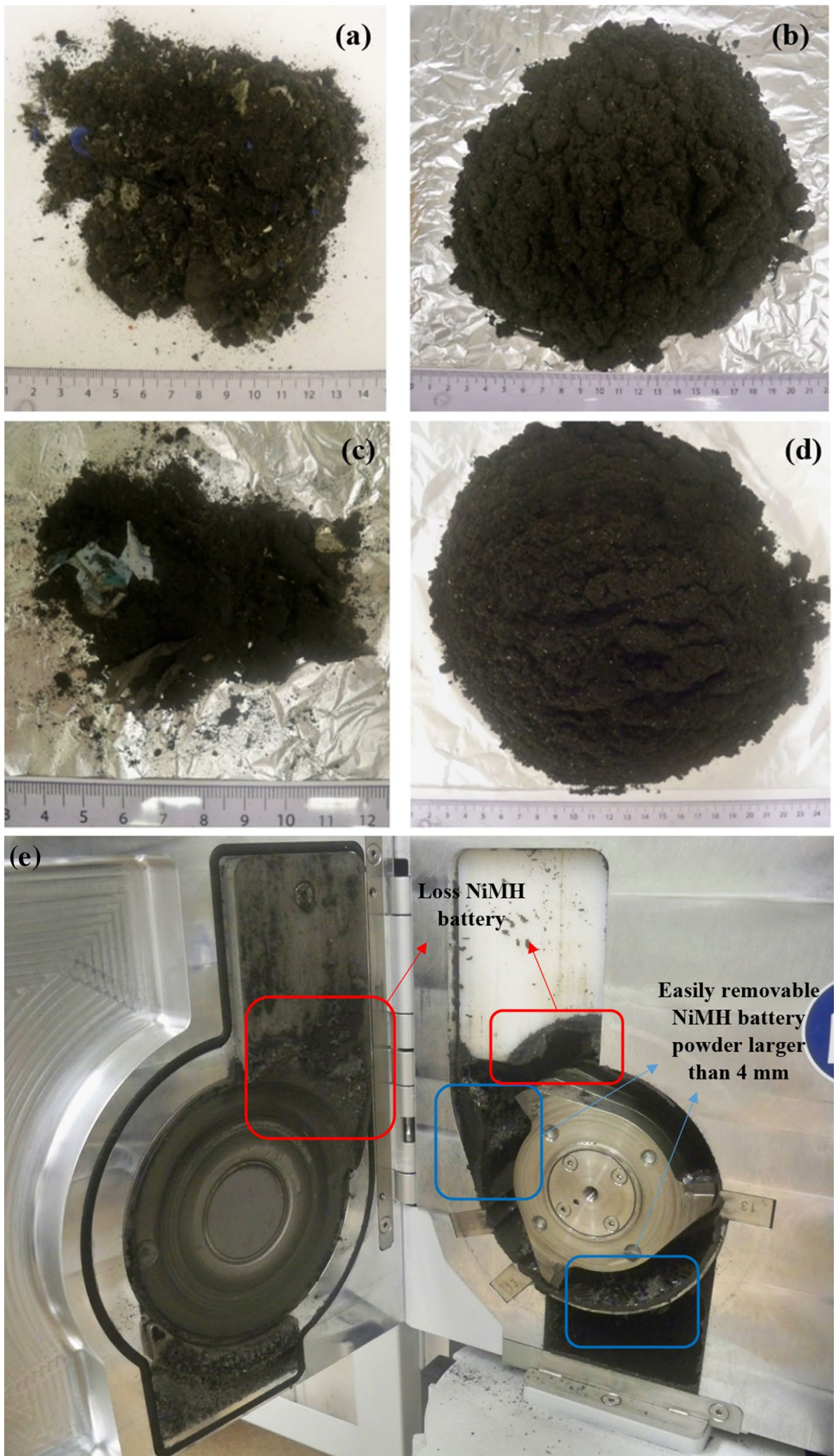

a step size of 0.04 and a wavelength of $1.541874 \AA$. The chemical compositions of the samples, which are smaller than $4 \mathrm{~mm}$ and all subsize fractions, were analyzed by inductive coupled plasma optical emission spectrometry (ICP-OES, ICAP 6500, Thermo Fischer). The battery black mass, $0.2 \mathrm{~g}$ powder, were dissolved in $30 \mathrm{~mL}$ aqua 
regia $\left(\mathrm{HNO}_{3}+3 \mathrm{HCl}\right)$ and diluted in the desired amounts for the ICP-OES analyses. Carbon analyzer (Eltra Carbon/Sulfur Analyzer CS-800) was used to determine the amount of carbon in the battery black mass.

\section{Results and discussion}

Total mass distributions of the three fractions, which are smaller than $4 \mathrm{~mm}$, coarser than $4 \mathrm{~mm}$, and loss, were analyzed after grinding process to evaluate the recyclable amount. Figure 4 shows the total mass distributions of the samples depending on grinding time. The weight of the fine fraction $(<4 \mathrm{~mm})$ increased from 76.8 to $86.9 \mathrm{wt} \%$ of total weight of the mechanically treated spent NiMH battery by elongating grinding duration. At the same time, the coarser fraction amount $(>4 \mathrm{~mm})$ sharply decreased from 9.7 to $1.0 \mathrm{wt} \%$ of the total weight. The generated heat during the mechanical treatment evaporates humidity from the battery waste. The solid loss part stuck on the

(a)

Weight distribution of grinded spent NiMH batteries for $5 \mathrm{~min}$

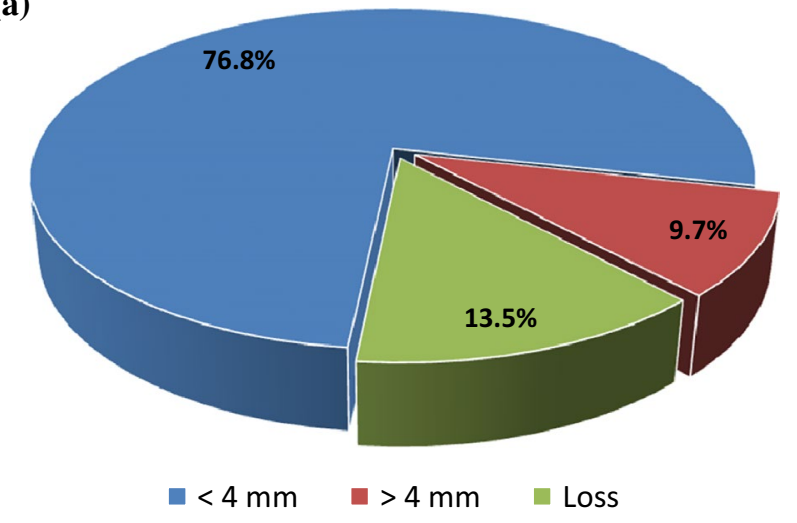

(b)

Weight distribution of grinded spent $\mathrm{NiMH}$ batteries for $10 \mathrm{~min}$

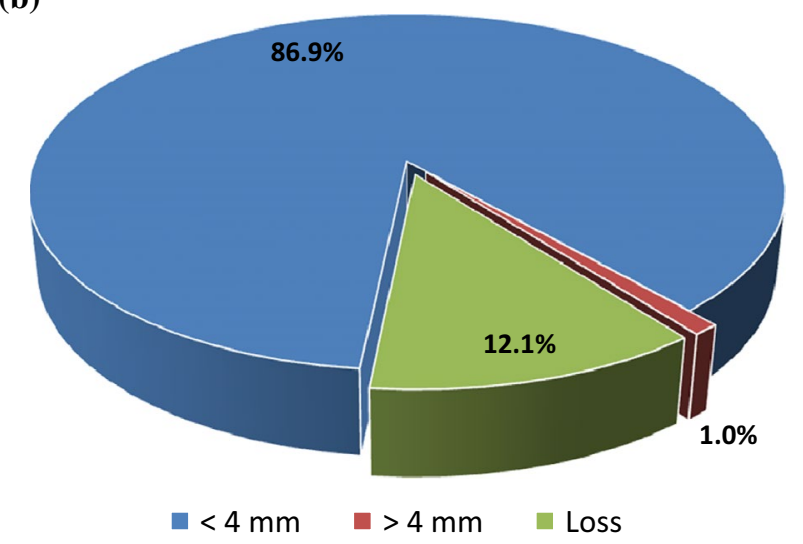

Fig. 4 Weight distribution of ground spent NiHM batteries for a $5 \mathrm{~min}$ and $\mathbf{b} 10 \mathrm{~min}$

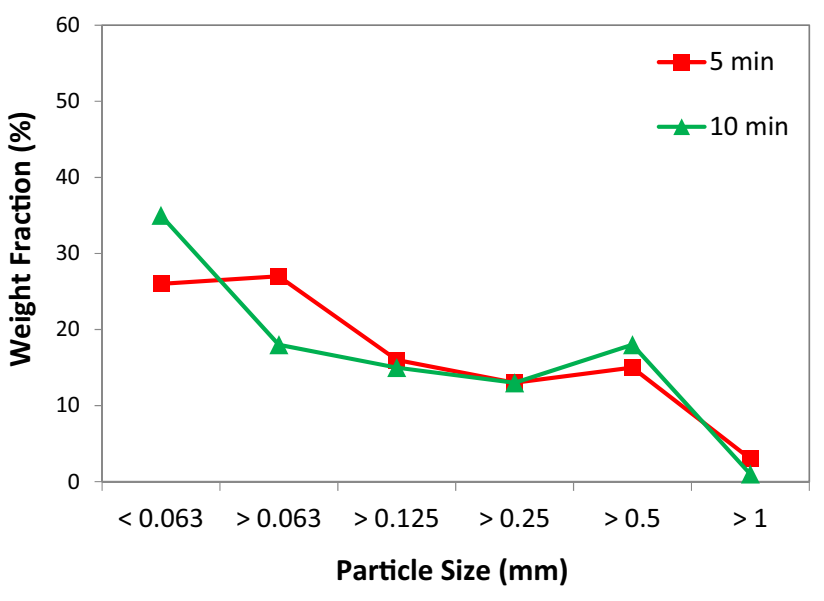

Fig. 5 Particle size distribution for the fine fractions $(<4 \mathrm{~mm})$ that ground for $\mathbf{a} 5 \mathrm{~min}$ and $\mathbf{b} 10 \mathrm{~min}$

equipment as it mentioned before. According to results, nearly $87 \mathrm{wt} \%$ of the NiMH batteries is suitable for further recycling after the suggested milling method. On the other hand, the coarser fraction is a complex mixture of the organic and inorganic battery parts, and especially battery powder coated onto the battery label (paper) and polymeric parts. The soft and flexible organic parts can plug the sieves. Considering the small fraction amount and also its possible side effect to the sieving step, finer sorting/ enrichment was applied only to fine fractions.

Particle size distribution for the fine fractions $(<4 \mathrm{~mm})$ of ground samples were measured by sieving analyses and results are given in Fig. 5. Weight fraction of the both samples are nearly same for size ranges between 0.125 and $4 \mathrm{~mm}$. Although the finest particle fraction $(<0.063 \mathrm{~mm})$ amount for the 10-min ground sample is higher than the shorter grinding time, the total weight fractions at $<0.125 \mathrm{~mm}$ size range for the both sample is equal, which is $53 \mathrm{wt} \%$.

Chemical composition of the fine fraction $(<4 \mathrm{~mm})$ of ground NiMH batteries for 5 and $10 \mathrm{~min}$ and the samples after size classification were detected as shown in Tables 1 and 2. The fine fraction of the battery black mass ground for $5 \mathrm{~min}$ contains nearly $44.3 \mathrm{wt} \% \mathrm{Ni}, 14.0 \mathrm{wt} \%$ $\mathrm{Fe}, 3.6 \mathrm{wt} \% \mathrm{Co}, 6.1 \mathrm{wt} \% \mathrm{La}, 1.7 \mathrm{wt} \% \mathrm{Nd}, 1.6 \mathrm{wt} \% \mathrm{Ce}$, $1.4 \mathrm{wt} \% \mathrm{Pr}$ and other minor elements. When we analyzed the chemical composition after the size classification, it was detected that $\mathrm{Ni}$ and Co contents increased in finer fractions smaller than $0.25 \mathrm{~mm}$. Fe showed an opposite behavior and enriched in the samples bigger than $0.25 \mathrm{~mm}$. REEs (La, Nd, Ce and Pr) content concentrated at very fine particle size range as also observed in lab-scale gravity separation from ores [31, 32]. REEs total amount reached to $15.3 \mathrm{wt} \%$ for NiMH battery black mass smaller than $0.063 \mathrm{~mm}$. 
The fine fraction of the battery black mass ground for 10 min contains nearly $44 \mathrm{wt} \% \mathrm{Ni}, 11.7 \mathrm{wt} \% \mathrm{Fe}, 4.9 \mathrm{wt} \%$ Co, 6.4 wt $\%$ La, 0.95 wt\% Nd, 2.14 wt $\%$ Ce, 0.89 wt $\%$ Pr and other minor elements. Larsson et al. [33] presented the metal distribution in HEV NiMH battery-one cell having almost similar composition comparing to AA- and AAA-type NiMH batteries except Fe amount. The analyzed HEV NiMH battery contained $30.8 \mathrm{wt} \% \mathrm{Fe}$, which is much higher than household-type NiMH batteries. After the size classification, the elemental distribution of the sample is nearly same as shorter time ground battery black mass. However, Ni, Co and REEs contents exhibit a positive linear relation with decreasing particle size. On the contrary, Fe mainly concentrated at coarser fraction and its amount sharply reduced by decreasing particle size. REEs total amount reached to $14.6 \mathrm{wt} \%$ for NiMH battery black mass smaller than $0.063 \mathrm{~mm}$, which is richer than most of the REE deposits [31, 32].

Table 3 shows the carbon composition of the NiMH battery black mass depending on particle size. It is clear that organic components, which passed through the 4-mm sieve during the mechanical treatment, such as separator and battery label, can be easily separated from finer fraction by sieving. The carbon analysis results for $>1 \mathrm{~mm}$ sample fraction

Table 1 Elemental analyses of ground NiMH batteries for $5 \mathrm{~min}$, and after sieving as a function of particle size

\begin{tabular}{|c|c|c|c|c|c|c|c|}
\hline \multirow[t]{2}{*}{ Elements } & \multicolumn{7}{|c|}{ Ground sample for $5 \mathrm{~min}, \%(\mathrm{w} / \mathrm{w})$} \\
\hline & $<4 \mathrm{~mm}^{\mathrm{a}}$ & $>1 \mathrm{~mm}$ & $>0.5 \mathrm{~mm}$ & $>0.25 \mathrm{~mm}$ & $>0.125 \mathrm{~mm}$ & $>0.063 \mathrm{~mm}$ & $<0.063 \mathrm{~mm}$ \\
\hline $\mathrm{Al}$ & $0.85 \pm 0.011$ & $0.87 \pm 0.021$ & $0.14 \pm 0.002$ & $0.34 \pm 0.010$ & $1.45 \pm 0.036$ & $1.03 \pm 0.029$ & $0.98 \pm 0.018$ \\
\hline $\mathrm{Ce}$ & $1.55 \pm 0.005$ & $1.22 \pm 0.022$ & $0.04 \pm 0.008$ & $0.46 \pm 0.003$ & $1.34 \pm 0.034$ & $1.98 \pm 0.051$ & $2.38 \pm 0.054$ \\
\hline Co & $3.58 \pm 0.122$ & $3.36 \pm 0.076$ & $0.45 \pm 0.148$ & $1.59 \pm 0.035$ & $5.62 \pm 0.133$ & $4.70 \pm 0.047$ & $4.68 \pm 0.097$ \\
\hline $\mathrm{Fe}$ & $14.03 \pm 0.513$ & $10.53 \pm 0.291$ & $78.33 \pm 1.519$ & $33.12 \pm 0.288$ & $11.84 \pm 0.166$ & $1.82 \pm 0.020$ & $1.05 \pm 0.014$ \\
\hline $\mathrm{K}$ & $0.66 \pm 0.007$ & $0.84 \pm 0.022$ & $0.09 \pm 0.001$ & $0.34 \pm 0.005$ & $0.75 \pm 0.022$ & $0.73 \pm 0.022$ & $0.67 \pm 0.014$ \\
\hline $\mathrm{La}$ & $6.13 \pm 0.058$ & $5.37 \pm 0.098$ & $0.57 \pm 0.007$ & $1.96 \pm 0.015$ & $5.24 \pm 0.152$ & $7.69 \pm 0.214$ & $9.47 \pm 0.170$ \\
\hline $\mathrm{Mg}$ & $0.11 \pm 0.002$ & $0.07 \pm 0.002$ & - & - & $0.09 \pm 0.003$ & $0.17 \pm 0.006$ & $0.17 \pm 0.003$ \\
\hline $\mathrm{Mn}$ & $0.95 \pm 0.009$ & $0.91 \pm 0.024$ & $0.19 \pm 0.002$ & $0.34 \pm 0.005$ & $0.88 \pm 0.022$ & $1.18 \pm 0.031$ & $1.15 \pm 0.021$ \\
\hline $\mathrm{Na}$ & $0.35 \pm 0.005$ & $0.42 \pm 0.010$ & $0.05 \pm 0.002$ & $0.21 \pm 0.003$ & $0.48 \pm 0.013$ & $0.47 \pm 0.024$ & $0.36 \pm 0.005$ \\
\hline $\mathrm{Nd}$ & $1.67 \pm 0.019$ & $1.15 \pm 0.031$ & $0.07 \pm 0.006$ & $0.41 \pm 0.005$ & $1.44 \pm 0.041$ & $2.29 \pm 0.057$ & $2.30 \pm 0.060$ \\
\hline $\mathrm{Ni}$ & $44.34 \pm 1.695$ & $41.31 \pm 1.069$ & $9.03 \pm 0.774$ & $38.26 \pm 0.463$ & $53.69 \pm 1.054$ & $53.44 \pm 0.511$ & $49.82 \pm 1.004$ \\
\hline $\operatorname{Pr}$ & $1.40 \pm 0.004$ & $1.00 \pm 0.016$ & $0.03 \pm 0.005$ & $0.39 \pm 0.004$ & $1.13 \pm 0.033$ & $1.75 \pm 0.050$ & $2.19 \pm 0.048$ \\
\hline $\mathrm{Zn}$ & $1.28 \pm 0.017$ & $1.18 \pm 0.029$ & $0.14 \pm 0.003$ & $0.74 \pm 0.005$ & $1.57 \pm 0.032$ & $1.51 \pm 0.040$ & $1.54 \pm 0.016$ \\
\hline
\end{tabular}

${ }^{\text {a } A l l ~ o f ~ t h e ~ s a m p l e s ~ f i n e r ~ t h a n ~} 4 \mathrm{~mm}$ after grinding

Table 2 Elemental analyses of ground NiMH batteries for $10 \mathrm{~min}$, and after sieving as a function of particle size

\begin{tabular}{|c|c|c|c|c|c|c|c|}
\hline \multirow[t]{2}{*}{ Elements } & \multicolumn{7}{|c|}{ Ground sample for $10 \mathrm{~min}, \%(\mathrm{w} / \mathrm{w})$} \\
\hline & $<4 \mathrm{~mm}^{\mathrm{a}}$ & $>1 \mathrm{~mm}$ & $>0.5 \mathrm{~mm}$ & $>0.25 \mathrm{~mm}$ & $>0.125 \mathrm{~mm}$ & $>0.063 \mathrm{~mm}$ & $<0.063 \mathrm{~mm}$ \\
\hline $\mathrm{Al}$ & $0.92 \pm 0.068$ & $0.10 \pm 0.002$ & $0.25 \pm 0.003$ & $0.46 \pm 0.001$ & $0.67 \pm 0.004$ & $0.82 \pm 0.019$ & $1.17 \pm 0.030$ \\
\hline $\mathrm{Ce}$ & $2.14 \pm 0.148$ & $0.18 \pm 0.004$ & $0.49 \pm 0.009$ & $0.96 \pm 0.013$ & $1.64 \pm 0.017$ & $2.26 \pm 0.052$ & $2.98 \pm 0.121$ \\
\hline Co & $4.90 \pm 0.384$ & $0.54 \pm 0.006$ & $1.35 \pm 0.025$ & $2.73 \pm 0.015$ & $4.42 \pm 0.018$ & $5.52 \pm 0.116$ & $6.99 \pm 0.197$ \\
\hline $\mathrm{Fe}$ & $11.70 \pm 0.806$ & $66.21 \pm 0.498$ & $57.79 \pm 0.765$ & $27.83 \pm 0.156$ & $6.93 \pm 0.013$ & $4.30 \pm 0.094$ & $1.93 \pm 0.049$ \\
\hline $\mathrm{K}$ & $1.15 \pm 0.088$ & $0.21 \pm 0.002$ & $0.42 \pm 0.006$ & $0.72 \pm 0.002$ & $1.29 \pm 0.435$ & $1.14 \pm 0.027$ & $1.37 \pm 0.023$ \\
\hline $\mathrm{La}$ & $6.41 \pm 0.455$ & $0.72 \pm 0.005$ & $1.51 \pm 0.020$ & $3.16 \pm 0.029$ & $5.31 \pm 0.013$ & $7.31 \pm 0.155$ & $9.05 \pm 0.338$ \\
\hline $\mathrm{Mg}$ & $0.003 \pm 0.001$ & - & - & - & - & $0.012 \pm 0.002$ & $0.002 \pm 0.0003$ \\
\hline $\mathrm{Mn}$ & $1.85 \pm 0.132$ & $0.30 \pm 0.005$ & $0.60 \pm 0.010$ & $0.81 \pm 0.003$ & $1.25 \pm 0.009$ & $1.70 \pm 0.038$ & $2.50 \pm 0.088$ \\
\hline $\mathrm{Na}$ & $0.09 \pm 0.010$ & - & - & $0.03 \pm 0.001$ & $0.07 \pm 0.001$ & $0.07 \pm 0.003$ & $0.10 \pm 0.002$ \\
\hline $\mathrm{Nd}$ & $0.95 \pm 0.064$ & $0.03 \pm 0.007$ & $0.15 \pm 0.008$ & $0.35 \pm 0.004$ & $0.62 \pm 0.006$ & $0.88 \pm 0.022$ & $1.33 \pm 0.055$ \\
\hline $\mathrm{Ni}$ & $43.95 \pm 3.207$ & $13.69 \pm 0.088$ & $22.02 \pm 0.342$ & $39.89 \pm 0.217$ & $45.78 \pm 0.164$ & $42.73 \pm 0.874$ & $48.57 \pm 1.338$ \\
\hline $\operatorname{Pr}$ & $0.89 \pm 0.066$ & $0.03 \pm 0.003$ & $0.14 \pm 0.001$ & $0.38 \pm 0.006$ & $0.71 \pm 0.004$ & $1.00 \pm 0.021$ & $1.24 \pm 0.046$ \\
\hline $\mathrm{Zn}$ & $1.11 \pm 0.077$ & $0.18 \pm 0.002$ & $0.36 \pm 0.003$ & $0.71 \pm 0.004$ & $1.05 \pm 0.002$ & $1.13 \pm 0.025$ & $1.31 \pm 0.023$ \\
\hline
\end{tabular}

${ }^{\mathrm{a}}$ All of the samples finer than $4 \mathrm{~mm}$ after grinding 
Table 3 Carbon analyses of ground NiMH batteries for 5 and 10 min as a function of particle size

\begin{tabular}{lll}
\hline Particle size & \multicolumn{2}{l}{ Carbon amount w\% } \\
\cline { 2 - 3 } & Ground sample for 5 min & $\begin{array}{l}\text { Ground } \\
\text { sample for } \\
10 \mathrm{~min}\end{array}$ \\
\hline$<4 \mathrm{~mm}^{\mathrm{a}}$ & $3.58 \pm 0.8301$ & $3.05 \pm 0.532$ \\
$>1 \mathrm{~mm}$ & $7.03 \pm 3.61$ & $7.29 \pm 4.13$ \\
$>0.5 \mathrm{~mm}$ & $5.44 \pm 1.230$ & $1.93 \pm 0.901$ \\
$>0.025 \mathrm{~mm}$ & $2.45 \pm 0.920$ & $4.74 \pm 1.41$ \\
$>0.0125 \mathrm{~mm}$ & $2.34 \pm 0.634$ & $3.37 \pm 0.796$ \\
$>0.0063 \mathrm{~mm}$ & $2.00 \pm 0.142$ & $2.99 \pm 0.315$ \\
$<0.0063 \mathrm{~mm}$ & $2.10 \pm 0.132$ & $2.94 \pm 0.18$ \\
\hline
\end{tabular}

${ }^{\mathrm{a}}$ All of the samples finer than $4 \mathrm{~mm}$ after grinding presents high standard deviation due to heterogeneous composition of organic parts, iron and nickel-based components. The amount of the organic content has a decreasing trend by reducing particle size. Reducing the carbon amount can be beneficial for the further recycling step for $\mathrm{Ni}$ and REEs which is leaching and solvent extraction. Ni and REEs can be adsorbed by various carbonaceous materials [34-39]. Thus high carbon amount can reduce the leaching efficiency of the valuable metals due to adsorption features of carbon. Moreover, carbon and organic compounds cause a problem in the filtration step of the leachate after dissolution of the metallic content [40].

XRD pattern of the samples is given in Fig. 6. The total battery black masses $(<4 \mathrm{~mm})$ for both grinding durations have a complex phase structure, and mainly contains nickelbased hydrogen storage alloy, $\mathrm{Ni}(\mathrm{OH})_{2}$, iron and nickel. The
Fig. 6 XRD pattern of the ground samples for $\mathbf{a} 5 \mathrm{~min}$ and b $10 \mathrm{~min}$
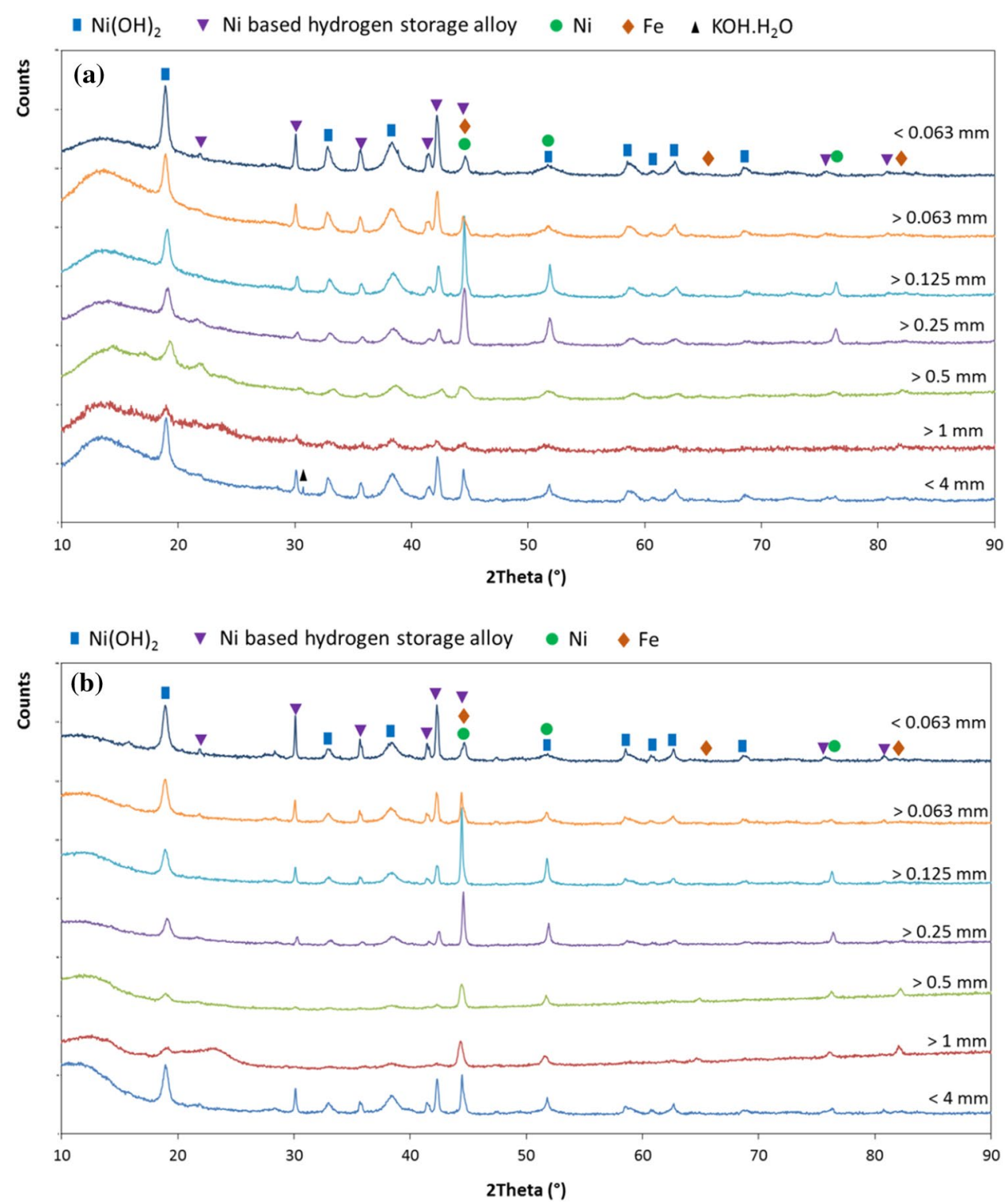
characteristic diffraction peaks of $\mathrm{Ni}(\mathrm{OH})_{2}$ (PDF Card no.: 04-013-4402) can be clearly observed at $19.1^{\circ}, 33.0^{\circ}$ and $38.5^{\circ} 2 \theta$ degrees. The overt peaks at $30.1^{\circ}, 35.8^{\circ}, 41.7^{\circ}$, $42.3^{\circ}$ and $44.6^{\circ} 2 \theta$ degrees are indexed with $\mathrm{AB}_{5^{-}}$-type hydrogen storage alloys $\left[\mathrm{La}_{0.5} \mathrm{Ce}_{0.3} \mathrm{Pr}_{0.1} \mathrm{Nd}_{0.1}(\mathrm{Ni}, \mathrm{Co}, \mathrm{Al}, \mathrm{Mn})_{5}\right.$, PDF Card no.: 04-008-6028 and 04-019-4647]. The highest peak (110) of body centered cubic Fe and Ni locate nearly same position at around $44.5^{\circ} 2 \theta$ degree. Although it is difficult to distinguish them, (200) and (220) diffractions of Fe were detected at $65.8^{\circ}$ and $82.5^{\circ} 2 \theta$ degrees, as well as (200) and (220) diffractions of $\mathrm{Ni}$ were identified at $51.9^{\circ}$ and $76.6^{\circ}$ $2 \theta$ degrees. The majority of the peaks for the smaller fraction of the samples, $>0.063 \mathrm{~mm}$ and $<0.063 \mathrm{~mm}$, represent the existence of $\mathrm{Ni}(\mathrm{OH})_{2}$ and nickel-based hydrogen storage alloy in the structure. XRD patterns of the ground sample for 10 min obviously show that Fe peaks became dominant for the coarser samples, $>1$ and $>0.5 \mathrm{~mm}$.

The mass balance for the mechanical treatment of the spent NiMH batteries was calculated for $1000 \mathrm{~g}$ starting material amount using experimentally obtained data for the 10-min ground sample. This sample was chosen for the mass balance because of the high material collection amount for fine fraction $(<4 \mathrm{~mm})$, which is rich in valuable metal content. Figure 7 presents the mass balance of the studied mechanical treatment method for the 10-min ground spent $\mathrm{NiMH}$ batteries. The difference between the masses of the samples and cumulative masses of the analyzed elements is due to the existence of other elements, such as oxygen, hydrogen and non-metallic components. The majority of the ground battery waste is collected in the fine particle size fraction which is smaller than $4 \mathrm{~mm}$. After sorting the fine fraction by size, it is clear that main Fe amount by weight resides in size fraction bigger than $0.25 \mathrm{~mm}$ with considerable amount of Ni. REEs and $\mathrm{Ni}$ by weight were enriched in the size fraction smaller than $0.25 \mathrm{~mm}$.

\section{Conclusion}

Valuable contents of the NiMH battery waste were successfully enriched by a simple mechanical pretreatment. After mechanical pretreatment nearly $87 \mathrm{wt} \%$ of the NiMH battery waste is suitable for further recycling steps due to its high valuable metal content. The ground samples were sieved and then chemical and material characterization methods were applied to all of the samples, smaller than $4 \mathrm{~mm}$, and the six different size fractions. The results clearly showed that $\mathrm{Fe}$ content was enriched in the coarser fraction of undersize of $4,>0.25 \mathrm{~mm}$, while $\mathrm{Ni}$ and REEs amounts were concentrated in the finer fractions $(<0.25 \mathrm{~mm})$. Thus after grinding, size classification by sieving is a simple but an efficient step to enrich the metal contents in a specific size fraction. Organic content of the battery black mass reduced by decreasing particle size, which can ease the further leaching and filtration steps. The phase composition of the finer fractions is mainly $\mathrm{AB}_{5}$-type nickel-based hydrogen storage alloy and nickel hydroxide. The mechanical pretreatment is a simple and efficient enrichment method which can help to reduce chemical consumption in a hydrometallurgical $\mathrm{NiMH}$ battery recycling process.

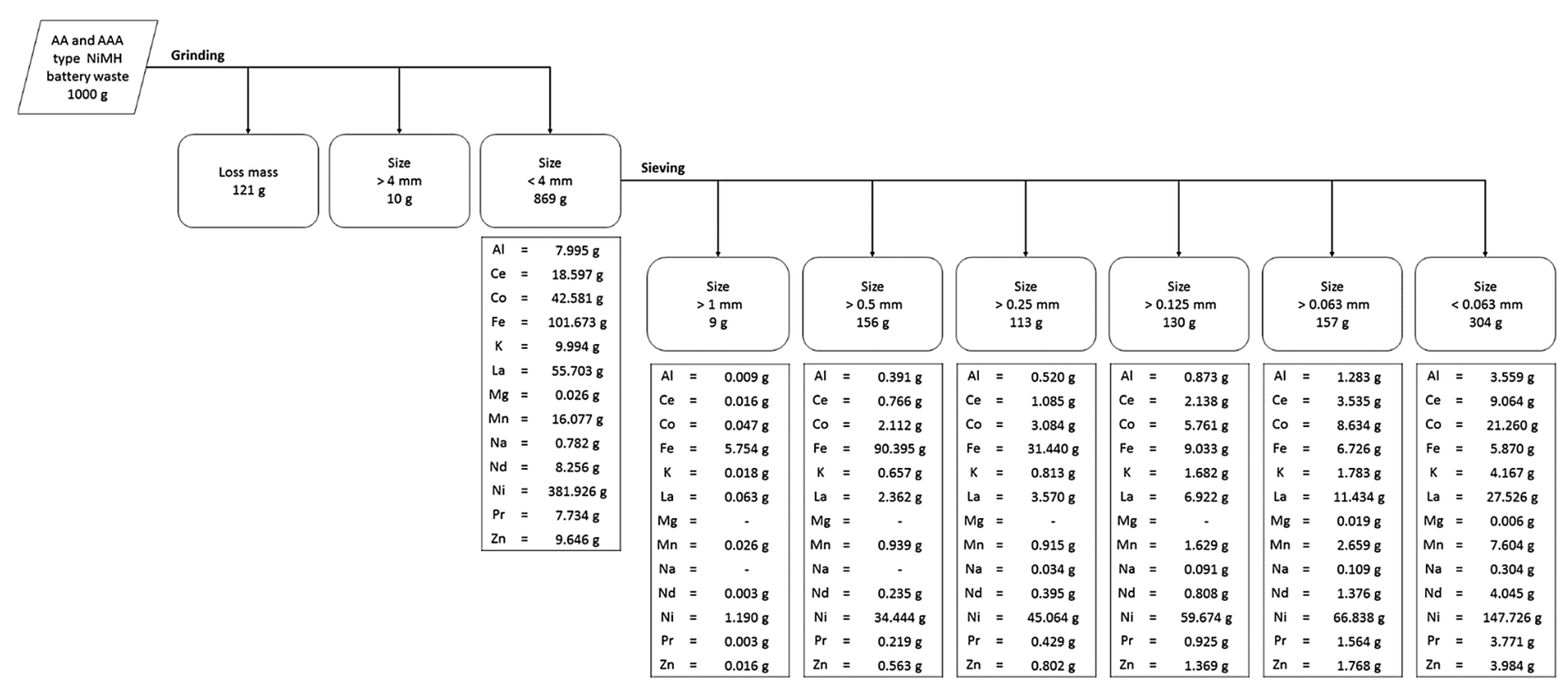

Fig. 7 Mass balance for mechanical treatment of spent NiMH batteries for the 10-min ground sample (the difference between the masses of the samples and cumulative masses of the analyzed elements is due to the existence of other elements, such as oxygen, hydrogen, etc., and non-metallic components) 
Various types of household battery waste such as spent alkaline, NiMH and lithium-ion batteries are generally collected together, and then a sorting depending on battery chemistry is required for the recycling. Thus further research should focus on mechanical treatment and enrichment of the other battery types especially lithium-ion batteries and also mixed battery waste to develop alternative processes and sustainable waste management strategies for batteries.

Acknowledgements This research was supported by Swedish Energy Agency, Battery-fund program (Grant no.: 37714-1). The authors would also like to thank Renova $\mathrm{AB}$ Gothenburg for providing the industrial collected battery waste.

Open Access This article is distributed under the terms of the Creative Commons Attribution 4.0 International License (http://creativeco mmons.org/licenses/by/4.0/), which permits unrestricted use, distribution, and reproduction in any medium, provided you give appropriate credit to the original author(s) and the source, provide a link to the Creative Commons license, and indicate if changes were made.

\section{References}

1. Thackeray MM, Wolverton C, Isaacs ED (2012) Electrical energy storage for transportation-approaching the limits of, and going beyond, lithium-ion batteries. Energy Environ Sci 5:7854-7863

2. Chen H, Cong TN, Yang W, Tan C, Li Y, Ding Y (2009) Progress in electrical energy storage system: a critical review. Prog Nat Sci 19(3):291-312

3. Pollet BG, Staffell I, Shang JL (2012) Current status of hybrid, battery and fuel cell electric vehicles: from electrochemistry to market prospects. Electrochim Acta 84:235-249

4. Fetcenko MA, Ovshinsky SR, Reichman B, Young K, Fierro C, Koch J, Zallen A, Mays W, Ouchi T (2007) Recent advances in MiMH battery technology. J Power Sources 165:544-551

5. Gibson E, van Blommestein K, Kim J, Daim T. Garces E (2017) Forecasting the electric transformation in transportation: the role of battery technology performance. Technol Anal Strateg Manag 29:1103-1120

6. Echandia Marine Sweden AB. http://www.echandiamarine.com/ products.html. Accessed 14 Dec 2017

7. Zolot MD, Kelly K, Pesaran A, Keyser M, Mihalic M, Hieronymus A (2001) Thermal evaluation of the Honda Insight battery pack. In: Proceedings of the intersociety energy conversion engineering conference, vol 2, pp 923-928

8. Hamada S, Eto T (2007) Battery pack, United States Patent, Patent no.: US 7189474B", Mar. 13

9. Pillot C (2013) Micro hybrid, HEV, P-HEV and EV market 20122025 impact on the battery business. In: Proceedings of world electric vehicle symposium and exhibition (EVS27), pp 1-6

10. Bertin FCH, Espinosa DCR, Tenório JAS, Tanabe EH, Bertuol DA, Foletto EL, da Costa AJ (2015) Batteries. In: Veit H, Moura Bernardes A (eds) Electronic waste. Topics in mining, metallurgy and materials engineering. Springer, Cham, pp 129-158

11. Müller T, Friedrich B (2006) Development of a recycling process for nickel-metal hydride batteries. J Power Sources 158(2):1498-1509

12. Communication from the commission to the European Parliament, the council, the European economic and social committee and the committee of the regions on the 2017 list of Critical Raw
Materials for the EU. http://eur-lex.europa.eu/legal-content/EN/ ALL/?uri=COM:2017:0490:FIN. Accessed 11 Nov 2017

13. Yano J, Muroi T, Sakai S-I (2016) Rare earth element recovery potentials from end-of-life hybrid electric vehicle components in 2010-2030. J Mater Cycles Waste Manag 18:655-664

14. Pietrelli L, Bellomo B, Fontana D, Montereali M (2005) Characterization and leaching of $\mathrm{NiCd}$ and $\mathrm{NiMH}$ spent batteries for the recovery of metals. Waste Manag 25:221-226

15. Meshram P, Somani H, Pandey BD, Mankhand TR, Deveci H, Abhilash (2017) Two stage leaching process for selective metal extraction from spent nickel metal hydride batteries. J Clean Prod 157:322-332

16. Innocenzi V, Veglio F (2012) Separation of manganese, zinc and nickel from leaching solution of nickel-metal hydride spent batteries by solvent extraction. Hydrometallurgy 129-130:50-58

17. Shengqiang Z, Xiuyang H, Dahui W (2015) Review on comprehensive recovery of valuable metals from spent electrode materials of nickel-hydrogen batteries. Rare Metal Mater Eng 44:73-78

18. Bertuol DA, Bernardes AM, Tenório JAS (2009) Spent NiMH batteries - the role of selective precipitation in the recovery of valuable metals. J Power Sources 193:914-923

19. Nan J, Han D, Yang M, Cui M, Hou X (2006) Recovery of metal values from a mixture of spent lithium-ion batteries and nickelmetal hydride batteries. Hydrometallurgy 84:75-80

20. Petranikova M, Herdzik-Koniecko I, Steenari B-M, Ekberg C (2017) Hydrometallurgical processes for recovery of valuable and critical metals from spent car NiMH batteries optimized in a pilot plant scale. Hydrometallurgy 171:128-141

21. Innocenzi V, Ippolito NM, Michelis ID, Prisciandaro M, Medici F, Vegliò $F$ (2017) A review of the process and lab-scale techniques for the treatment of spent rechargeable NiMH batteries. J Power Sources 362:202-218

22. Al-Thyabat S, Nakamura T, Shibata E, Iizuka A (2013) Adaptation of minerals processing operations for lithium-ion ( $\mathrm{LiBs})$ and nickel hydride (NiMH) batteries: critical review. Miner Eng 45:4-17

23. A.Bouvier A, Fölzer K, Kelinsorgen U, Köhler (1999) Patent No. EP 0806059B1, Process for recovery of metals from used nickel/ metalhydride storage batteries. Anmelder, Varta Batterie AG, Hannover

24. Granata G, Pagnanelli F, Moscardini E, Takacova Z, Havlik T, Toro L (2012) Simultaneous recycling of nickel metal hydride, lithium ion and primary lithium batteries: accomplishment of European Guidelines by optimizing mechanical pre-treatment and solvent extraction operations. J Power Sources 212:205-211

25. Bertuol DA, Bernardes AM, Tenório JAS (2006) Spent NiMH batteries: characterization and metal recovery through mechanical processing. J Power Sources 160:1465-1470

26. Huang K, Li J, Xu Z (2011) Enhancement of the recycling of waste $\mathrm{Ni}-\mathrm{Cd}$ and $\mathrm{Ni}-\mathrm{MH}$ batteries by mechanical treatment. Waste Manag 31:1292-1299

27. Tenório JAS, Espinosa DCR (2002) Recovery of Ni-based alloys from spent NiMH batteries. J Power Sources 108:70-73

28. Tanabe EH, Schlemmer DF, Aguiar ML, Dotto GL, Bertuol DA (2016) Recovery of valuable materials from spent NiMH batteries using spouted bed elutriation. J Environ Manag 171:177-183

29. Czerny T, Reichel W (1999) Patent No. DE 19727880A1, Verfahren zur Valuable material recovery from nickel/metal hydride cells, Anmelder, Varta Batterie AG. Kali-Umwelttechnik GmbH. Hannover

30. Ruffino B, Zanetti MC, Marini P (2011) A mechanical pre-treatment process for the valorization of useful fractions from spent batteries. Resour Convers Recycl 55(3):309-315

31. Zhang J, Zhao B, Schreiner B (2016) Rare earth beneficiation and hydrometallurgical processing. In: Separation hydrometallurgy of rare earth elements. Springer, Cham 
32. Özbayoğlu G, Atalay M (2000) Beneficiation of bastnaesite by a multi-gravity separator. J Alloy Compd 303-304:520-523

33. Larsson K, Ekberg C, Ødegaard-Jensen A (2013) Dissolution and characterization of HEV NiMH batteries. Waste Manag 33:689-698

34. Lee C-G, Lee S, Park J-A, Park C, Lee SJ, Kim S-B, An B, Yun S-T, Lee S-H, Choi J-W (2017) Removal of copper, nickel and chromium mixtures from metal plating wastewater by adsorption with modified carbon foam. Chemosphere 166:203-2011

35. Kandah MI, Meunier J-L (2007) Removal of nickel ions from water by multi-walled carbon nanotubes. J Hazard Mater 146:283-288

36. Kadirvelu K, Thamaraiselvi K, Namasivayam C (2001) Removal of heavy metals from industrial wastewaters by adsorption onto activated carbon prepared from an agricultural solid waste. Biores Technol 76(1):63-65

37. Smith YR, Bhattacharyya D, Willhard T, Misra M (2016) Adsorption of aqueous rare earth elements using carbon black derived from recycled tires. Chem Eng J 296:102-111

38. Li C, Zhuang Z, Huang F, Wu Z, Hong Y, Lin Z, Recycling rare earth elements from industrial wastewater with flowerlike nano$\mathrm{Mg}(\mathrm{OH})_{2}$. Appl Mater Interfaces 5:9719-9725

39. Anastopoulos I, Bhatnagar A, Lima EC (2016) Adsorption of rare earth metals: a review of recent literature. J Mol Liq 221:954-962

40. Shin SM, Kim NH, Sohn JS, Yang DH, Kim YH (2005) Development of a metal recovery process from Li-ion battery wastes. Hydrometallurgy 79:172-181 